\section{Principios y actualidad de la experiencia mística en San Juan de la Cruz*}

\author{
Lucero GonZÁlez SuÁrez **
}

RECIBIDO: 10-06-15. APROBADO: 20-10-15

Resumen: Pretende dilucidar los principios de la experiencia mística propuestos por San Juan de la Cruz, con el objeto de justificar la afirmación de que el único medio proporcionado para la realización del fin sobrenatural para el cual fuimos creados es la virtud sobrenatural de la fe, que Dios infunde en contemplación. Para ello, la autora sigue los postulados metodológicos de la fenomenología hermenéutica de la mística.

Palabras clave: Mística, San Juan de la Cruz, fe sobrenatural, Dios.

PARA CITAR ESTE ARTÍCULO:

González Suárez, Lucero. "Principios y actualidad de la experiencia mística en San Juan de la Cruz". Theologica Xaveriana 181 (2016): 147-175. http:// dx.doi.org/10.11144/javeriana.tx66-181.paemsjc
Principles and Currency of the Mystical Experience in Saint John of the Cross

Aвstract: This articles attempts to elucidate the principles of the mystical experience proposed by Saint John of the Cross, in order to justify the affirmation that the only given means to the fulfillment of the supernatural end to which all of us were created is the supernatural virtue of faith, which is inspired by God during contemplation. To do this, the autor will follow the methodological postulates of the hermeneutical phenomenology of the mystic.

Key words: Mystic, Saint John of the Cross, supernatural faith, God.

Princípios e atualidade da experiência mística em San Juan de la Cruz

Resumo: Pretende esclarecer os princípios da experiência mística propostas por San Juan de la Cruz, com o objetivo de justificar a afirmação de que o único meio proporcionado para a realização do fim sobrenatural para o qual fomos criados é a virtude sobrenatural da fé, que Deus infunde em contemplação. Para ele a autora os postulados metodológicos da fenomenologia hermenêutica da mística.

Palavra chave: Mística, San Juan de la Cruz fé sobrenatural, Deus.

* El presente artículo forma parte del proyecto de investigación "La purificación de los apetitos en la noche activa del sentido. Una fenomenología hermenéutica de la "Subida del Monte Carmelo" de San Juan de la Cruz", que se realiza en el Departamento de Filosofía, Universidad Iberoamericana, México, D.F., con apoyo del Conacyt (México).

** Doctora, Maestra y Licenciada en Filosofía, Universidad Nacional Autónoma de México. Realiza el segundo ańo del posdoctorado en la Universidad Iberoamericana, México, D. F., donde es profesora de asignatura en el Departamento de Ciencias Religiosas. Correo electrónico: noche_oscura27@yahoo.com.mx 
Vivimos en una época que habla del Dios lejano y silencioso

[...]. Para tener el valor de aceptar esa manifestación silenciosa de Dios como el verdadero misterio de la propia existencia se necesita evidentemente algo más que una toma de posición racional ante el problema teórico de Dios [...]. Se necesita una mistagogía o iniciación a la experiencia religiosa.

¿Dónde se dan todavía los "padres espirituales", los gurús cristianos, que poseen el carisma de iniciar en la meditación, en la mistica incluso...

Karl Rahner

\section{Introducción}

$\mathrm{Al}$ abordar la investigación del misticismo, en orden de importancia, la primera pregunta a resolver es la que interroga por las condiciones de posibilidad de la experiencia radical de encuentro con Dios que el término designa. Eso equivale a preguntar por los principios que han de confluir, a efecto de que tenga lugar la transformación de semejanza amorosa que iguala al hombre con Dios, que deja a la amada en el amado transformada.

El presente artículo tiene un doble propósito:

- En primer lugar, explicar los principios místico-teológicos de la unión amorosa con Dios propuestos por San Juan de la Cruz en la "Subida del Monte Carmelo", desde una perspectiva fenomenológica y, al mismo tiempo, hermenéutica. Es decir, poner entre paréntesis toda doctrina teológica o filosófica sobre el ser del hombre y sobre la noción de Dios, a fin de atender únicamente a la interpretación de lo dicho por San Juan de la Cruz respecto del modo en que tiene lugar el acontecer del misterio de Dios, que transforma al hombre en Dios por participación. Se trata de dilucidar los rasgos esenciales de la mística como modalidad de la vida fáctica abierta a todo hombre, por medio del análisis hermenéutico del discurso en el que se recoge la experiencia de Dios, de la que San Juan de la Cruz da cuenta de modo magistral.

La importancia del análisis hermenéutico que pretendo llevar a cabo, tomando como punto partida la descripción que San Juan de la Cruz hace de la experiencia mística, en tanto que modo de comprensión de lo divino y del ser que somos, radica en que lo dicho por el santo no solo nos permite entender su camino de perfección espiritual sino el proceso de transformación amorosa que tiene lugar en todo aquel que, al ser interpelado por el llamado amoroso del buen Pastor, en actitud de total disponibilidad, responde "heme aqui". 
El objetivo es exhibir las razones por la cuales, con base en su experiencia y en la autoridad de la revelación -cuyo valor no es otro que el de ser una experiencia fundacional de lo divino que, por lo mismo, se convierte en el criterio último apelando al cual la tradición cristiana discrimina la experiencia místico-religiosa auténtica y la espuria ${ }^{1}-$, en contra de los defensores de la analogía, el poeta místico sostiene que en virtud de la infinita desproporción entre el ser sobrenatural de Dios y el alcance de las facultades naturales por medio de las cuales conocemos (entendimiento, voluntad y memoria), ninguna noticia proveniente de estas últimas permite al hombre acceder al misterio de Dios. A tal conclusión se agrega la advertencia de que solo la virtud de la fe teologal, que por ser don divino participa del ser sobrenatural de Dios, es medio proporcionado para la realización del fin para el cual fuimos creados: el conocimiento amoroso de Dios, efecto de la iluminación del Verbo, que Dios infunde en contemplación.

- $\quad$ En segundo lugar, aclarado lo anterior, la intención es mostrar la actualidad de la doctrina sanjuanista sobre el origen y las condiciones de posibilidad de la experiencia mística, en la época de la secularización, donde todo parecería apuntar a que "Dios ha muerto".

A fin de realizar el doble propósito recién enunciado, en la primera sección de este artículo se abordan cada uno de los principios de la mística sanjuanista, para esclarecer su sentido. En la segunda sección, se exhiben los rasgos esenciales de la fe sobrenatural, a partir de la interpretación del poema "Entréme donde no supe. Coplas del mismo hechas sobre un éxtasis de harta contemplación”. El tercer apartado está dedicado a la reflexión sobre la actualidad de la doctrina sanjuanista sobre el origen y las condiciones de posibilidad de la experiencia mística. Su propósito es responder a la pregunta que Karl Rahner se hiciera años atrás, y que sirve de epígrafe a esta meditación filosófico-teológica, argumentando que luego del silencio provocado por la crisis de la representación metafísica de lo divino, la experiencia mística de la que habla San Juan de la Cruz es la única vía por medio de la cual el hombre puede escuchar la voz de Dios.

En suma, el valor de este artículo deriva de la centralidad de la cuestión que aborda: la pregunta por los principios y la actualidad de la experiencia mística. Su originalidad radica en que, aun cuando el tema ha sido abordado en algunos textos

${ }^{1}$ En torno de la polémica de si entre religión y mística hay puntos de contacto o, por el contrario, se trata de posibilidades existenciales distintas, comparto la idea de que "la diferencia entre el místico y el creyente no místico será más gradual que esencial” (Gómez Caffarena, El misterio y el enigma, 217). 
sobre teología espiritual, así como en ensayos especializados sobre la doctrina de la salvación de San Juan de la Cruz, hasta donde tengo noticia, no ha habido ninguna aproximación para que, mediante la aplicación del método fenomenológico, se busque explicar los principios de la experiencia mística, a fin de mostrar que el encuentro radical con la presencia de Dios es obra de la gracia, pero reclama una disposición de apertura por parte del espiritual.

Por supuesto, no es mi propósito dejar finiquitada la cuestión, pues el solo hecho de pretender tal cosa en una extensión tan breve pondría de manifiesto un profundo desconocimiento de la profundidad de la teología mística de San Juan de la Cruz; pero sí lo es presentar algunas aportaciones para la comprensión de la experiencia mística sanjuanista, por medio del análisis hermenéutico de los pasajes de su obra donde de modo más claro se pronuncia sobre el tema, a fin de esclarecer el vínculo entre gracia, salvación y mérito.

\section{Principios místico-teológicos de la unión amorosa con Dios}

Cuando San Juan de la Cruz se pregunta si la experiencia mística surge de un llamado universal a la salvación o es obra de la predestinación, su posición es claramente paulina: Cristo murió para la salvación de todos, pues todos han pecado y todos necesitan ser redimidos del pecado para que, con el auxilio de la gracia, puedan acoger el don de la salvación que Cristo nos alcanzó en la cruz, en la entrega voluntaria de sí mismo en obediencia al Padre y por amor a cada uno de nosotros.

En contra de quienes piensan que la mística es una experiencia extraordinaria reservada a unos cuantos que Dios elige por razones misteriosas, San Juan de la Cruz afirma que cualquiera puede ser místico. Y para fundamentar dicha afirmación, en "Subida del Monte Carmelo" presenta cuatro principios con base en los cuales cabe comprender el carácter universal del misticismo.

\section{Primer principio: el fin sobrenatural de la vida es la unión mística}

A la pregunta de cuál es el origen y el sentido último de la existencia humana, el santo ofrece una misma respuesta: Dios, cuya esencia se identifica con el ejercicio perfecto del amor-ágape, quien nos creó por amor y para amar. El fin sobrenatural de la vida es la unión de semejanza amorosa con el esposo Cristo y, por medio suyo, con él y en él, la participación en la vida eterna de la santísima Trinidad, cuya sola actividad es el amor mutuo y el amor que tiene por destinatario al hombre. 
De acuerdo con el santo, "para este fin de amor fuimos creados" $\mathrm{y}$ su ejercicio supone "el más alto estado al que se puede llegar en esta vida" ${ }^{3}$. Como aclara E. Stein:

Dios ha creado las almas para sí. Dios quiere unirlas a sí y comunicarles la inconmensurable plenitud y la inconmensurable felicidad de su propia vida divina, y esto, ya aquí en la tierra. Esta es la meta hacia la que las orienta y a la que deben tender con todas sus fuerzas. ${ }^{4}$

Mas la unión no sería "verdadera y total transformación si no se transformase el alma en las tres personas en revelado y manifiesto grado"5.

En conformidad con el Evangelio según San Juan, el ser de Dios se ha manifestado plenamente en Cristo como entrega espontánea, gratuita e incondicional. Cristo es el buen pastor que, a lo largo de las generaciones, sale a buscar a todas y cada una de sus ovejas, llamándolas por su nombre para convocarlas a la vida eterna, sin tener en cuenta el mérito de sus acciones. Esto "descarta la cuestión de la mejor o peor naturaleza de quienes son objeto del amor divino. A la pregunta de por qué ama Dios, solo hay una respuesta justa: porque él es amor en su esencia" ${ }^{6}$.

Si Dios nos ama no es a causa de nuestros méritos, ni porque requiera de nuestra adoración; nos ama por ser el que es. Más aun, Dios nos ama a pesar de nosotros mismos, incluso cuando estamos inmersos en el error. Ya que, incluso cuando lo rechazamos y nos alejamos de su presencia, tal vez por pensar que no somos dignos de ella, espera pacientemente a que volvamos a su encuentro. $Y$ cuando lo hacemos, en vez de recriminarnos por nuestras faltas, nos perdona, $y$ al hacerlo nos infunde la fuerza para vivir de otro modo; para participar de la renovación de su amor. ${ }^{7}$

Mientras que el amor divino es originario, el amor místico es derivado. El amor que el sujeto religioso tiene a Dios es respuesta y no llamada. En palabras de San Agustín, Dios "nos amó primero para que nosotros, los amados, le amásemos a él $(1 \mathrm{Jn}$ 4,19)... Y aunque alguien se atribuya a sí mismo el obedecer a quien lo llama, nadie podrá atribuirse el haber sido llamado" ${ }^{8}$.

${ }^{2}$ San Juan de la Cruz, "Cántico espiritual B", canción 28, párrafo 3.

${ }^{3}$ Ibíd., canción 1, párrafo 11 .

${ }^{4}$ Stein, La ciencia de la cruz, 69.

${ }^{5}$ San Juan de la Cruz, "Cántico espiritual B”, canción 39, párrafo 3.

${ }^{6}$ Nygren, Eros y ágape. La noción cristiana del amor y sus transformaciones, 68.

${ }^{7}$ González, "La revelación del Evangelio según San Juan: Dios es amor", 272.

${ }^{8}$ San Agustín, “Textos de la Carta a los Romanos”, 7 [1, 1-7]. 
En total acuerdo con lo anterior, San Juan de la Cruz sostiene que Dios es amorágape, no para dar a entender que existe un ente absoluto tal que tiene por atributo esencial el amor, sino que el ser de Dios se esencia como amor-ágape: que el ser de Dios es donación libre, espontánea, inmerecida, universal, preeminente, gratuita y constante de sí, cuyo acontecer demanda una respuesta del hombre a quien se dirige.

En contra de lo que solemos pensar, el amor no es un predicado esencial ni accidental de Dios; no es una entidad de carácter accidental cuyo ser inhiere en un substrato (el ente absoluto "Dios").

El pensar representativo de la metafísica concibe a Dios como un ente absoluto. A la luz de la metafísica, "el ente es concebido como lo fundamentado, mientras que el ser asume la forma de ente supremo, fundamento causal del primero" .

"La constitución onto-teológica de la metafísica procede del predominio de la diferencia que mantiene separados y correlacionados mutuamente al ser en tanto que fundamento, y a lo ente en su calidad de fundado-fundamentador". $\mathrm{Al}$ establecer dicha relación entre el ente y el ser como fundamento óntico, "se ha mencionado ya el concepto metafísico de Dios. La metafísica ha de ir a parar al Dios con el pensamiento, porque el asunto del pensamiento es el ser, y este está presente de muchas maneras como fundamento". ${ }^{10}$

En contra del pensar representativo que cancela la divinidad de Dios al reducirlo a principio metafísico, el místico sabe por experiencia que el ser de Dios es sobrenatural y que, en consecuencia, está por encima de los modos de ser que nombran las categorías. Es decir, Dios no solo es el ente supremo, susceptible de ser definido como "aquello mayor que lo cual nada puede ser pensado"11, sino que incluso es aquello mayor que toda realidad susceptible de ser pensada, en el sentido de que ninguno de los modos de ser a los que apuntan las categorías recogidas en los Tratados de lógica, de Aristóteles, es adecuado para dar cuenta del misterio de Dios.

Dios no es un ente de mayor jerarquía ni una causa apelando a la cual se pueda explicar el origen del mundo; ante todo, es misterio salvífico, cuya esencia se define como gracia (en la terminología de la teología) y donación (en términos filosóficos) ${ }^{12}$,

\footnotetext{
${ }^{9}$ González, “Del concepto onto-teo-lógico de Dios a la comprensión fenomenológica de lo divino”, 127.

${ }^{10}$ Ibíd.

${ }^{11}$ San Anselmo, Proslogion, 11.

${ }^{12}$ Misterio salvífico es la categoría fenomenológica propuesta por Juan Martín Velasco, para designar la esencia analógica de lo divino, despojada de su representación personal o impersonal, monista o dualista, trascendente o inmanente. La realidad que ella mienta es el centro y origen de la vida religiosa y mística, en torno del cual se articulan los diversos aspectos del fenómeno correspondiente. Dicha categoría nombra
} 
y cuyo acontecer suscita la apertura del mundo de lo sagrado, entendido como el "ámbito de realidad que surge en la vida humana cuando el hombre vive su referencia al misterio"13.

La mayor complicación para comprender qué es el amor-ágape surge de su confusión con la noción de amor-eros. De ahí la necesidad de distinguirlos. Concebido como eros, el amor es un movimiento intencional, impulsado por el deseo de reencuentro y el anhelo de unidad y fusión totales, que puede orientarse a la fuente misma de donde mana la existencia, o bien apuntar hacia lo finito. El erotismo es esa ansiedad furiosa que hace a la existencia extasiarse, salir de sí para buscar la unión y la fusión plena con ese "algo" al que se desea poseer, valiéndose de todos los medios de que se dispone. La raíz del amor-eros es el deseo egoísta de posesión. Por tanto, si "el amor a Dios fuese un amor-deseo" (del que San Juan de la Cruz decía que no pasa de ser un apetito natural que ata al espiritual a un Dios-ídolo), "entonces Dios, aunque se le califique de 'bien supremo', no dejaría de ser un medio para satisfacer un deseo humano" 14 .

Por su parte, el amor-ágape aparece descrito en el Evangelio según San Juan como el ser de Dios. El texto revelado dice a la letra que si "el amor es de Dios, y todo el que ama ha nacido de Dios y conoce a Dios" (1Jn 4,7), es porque "Dios es amor" (1Jn 4,8). Para San Juan, el ser de Dios se ha manifestado plenamente en la cruz de Cristo, como entrega espontánea, gratuita e incondicional, que sale al encuentro de cada hombre para invitarlo a participar de la unión de semejanza consigo. Esto, para convocarlo a la realización del fin sobrenatural para el cual fue creado: el ejercicio del amor perfecto, que se manifestó en la cruz.

Ante el misterio de la cruz, la pregunta obligada es: ¿por qué, siendo lo que somos (como género) y quienes somos (cada uno de nosotros, con todas nuestras imperfecciones) Dios nos amó y nos sigue amando? El carácter incomprensible de la cruz no radica en que nos resulte imposible comprender la trascendencia de Dios, su perfección, ni su infinitud, sino su amor ilimitado, inmerecido y universal.

el "primer analogado" que la historia comparada de las religiones postula como hipótesis de investigación. Su sentido último no es ontológico sino metodológico. "Misterio salvífico" nombra la comunidad funcional que vincula las prácticas religiosas histórico-concretas. A través suyo las fenomenologías de la religión y de la mística designan la esencia de lo divino (lo que hace ser tales a Dios y a los dioses) valiéndose del pensamiento analógico que procede comparativamente. El correlato del concepto "misterio salvífico" es una abstracción que sirve para establecer puentes de contacto entre las diversas religiosidades y espiritualidades; no es la esencia subsistente, ni una substancia en sentido platónico.

${ }^{13}$ Martín Velasco, Introducción a la fenomenología de la religión, 109.

${ }^{14}$ Nygren, Eros y ágape, 85. 
La cruz es el ámbito donde tuvo lugar la revelación de la esencia divina como amor sacrificial y preeminente. El amor-ágape que Dios es consiste "no en que nosotros hayamos amado a Dios, sino en que él nos amó” (1Jn 4,10). El amor que el hombre tiene a Dios presupone el amor divino, pues "nosotros amamos porque él nos amó primero" (1Jn 4,19). Como ha señalado un intérprete de la mística sanjuanista:

Es el objeto del amor quien desencadena el proceso [místico-religioso]. Y lo inicia antes de que el amante sea consciente de ello. Lo cual significa, por una parte, que el amado es luz y guía del amante, antes de que conozca el objeto de su amor. ${ }^{15}$

En el interior de cada uno de nosotros hay un rastro del amor divino que nos indica cuál es el sentido último de la existencia; que nos hace comprender las palabras con las que San Agustín comienza sus Confesiones: “...nos creaste para ti e inquieto estará nuestro corazón hasta que descanse en $t \hat{\imath}{ }^{116}$.

El amor-ágape es entrega, donación libre de sí, ofrenda existencial. El amor cristiano es un vuelco del existente hacia aquello con lo que desea unirse, que busca cancelar la distancia afectiva y cognoscitiva entre amante y Amado, sin por ello aniquilar la diferencia ontológica entre ambos. Lo propio del amor-ágape es igualar amante y Amado; transformar al primero en semejanza del segundo, sin que ello implique la extinción de su identidad personal, de su conciencia o de su "yo". Si esto último ocurriera, ya no podría hablarse de unión con el Amado, sino de disolución en el Amado. El que ama busca encontrarse con el Amado en la silencio de la unión, sin que eso implique su absorción en un principio absoluto ${ }^{17}$.

El centro de la revelación, según el Evangelio según San Juan, reside en que Dios creó al hombre por amor y para amar en perfección. En total acuerdo con la doctrina de la salvación del Evangelio según San Juan, San Juan de la Cruz sostiene

\footnotetext{
${ }^{15}$ Ynduraín, “'Y pacerá el amado entre las flores’: la declaración en prosa”, 452.

${ }^{16}$ San Agustín, Confesiones, 19.

${ }^{17}$ Como es por todos sabido, una de las principales tipologías de la mística es la que distingue entre experiencias de unión (principalmente asociadas al judaísmo, al cristianismo y al islam) y experiencias de fusión (características del hinduismo y del sufismo). No obstante, con el propósito de hacer una descripción más fiel de la experiencia mística, conviene recordar que aun cuando en términos generales pueda decirse que en el cristianismo la finalidad de la vida se identifica con la unión con Dios, ello no cancela el hecho de que en el discurso de místicos como Santa Teresa de Jesús puedan encontrarse metáforas de la unión que tienen matices disolución en Dios. Con todo, la diferencia principal entre las místicas de unión y de fusión, consiste en que en las primeras el individuo ansía la unión con un ser personal, y en las segundas busca el retorno al principio del que todo procede y al que todo ha de volver, una vez cancelada la conciencia personal que hace del hombre un ser fragmentado o separado del absoluto.
} 
que hay una única vía para la justificación y salvación: la unión mística, que consiste en hacerse Dios por participación; pero a fin de realizar dicho propósito se precisa la intervención de la gracia. Porque si bien es cierto que para conocer y amar a Dios y al prójimo desde nuestra limitación e imperfección no necesitamos la intervención divina, también lo es que conocer a Dios y conocernos a nosotros mismos como seres que tienen su principio y fundamento en Dios, y amar como Cristo nos amó en la cruz, solo es posible cuando las operaciones de nuestras facultades (entendimiento, voluntad y memoria) son transformadas de naturales en sobrenaturales, por obra de Dios.

En conformidad con las sagradas Escrituras, Dios creó al existente para el fin sobrenatural de unirlo consigo, a fin de que pudiera conocerlo como él mismo se conoce en su Verbo, y amarlo con igual amor y modo con que Dios se ama y ama a cada uno de nosotros ${ }^{18}$. La unión mística consiste en ver a Dios "cara a cara, unida el alma con esta sabiduría divina, que es su Hijo" ${ }^{19}$. Mirar cara a cara a Dios es dejarse mirar por Cristo crucificado y resucitado. Porque, de acuerdo con San Juan de la Cruz, "el mirar de Dios es amar" y "la mirada de Dios cuatro bienes hace en el alma, es a saber: limpiarla, agraciarla, enriquecerla y alumbrarla" 20 .

${ }^{18}$ El conocimiento moderno, pretendidamente objetivo y libre de influjos afectivos, es un hallazgo intelectual detonado por la duda metódica, el aguijón del escepticismo y la avidez de certidumbre, cuya intención es prever y controlar el cauce de los fenómenos, a fin de minimizar el aspecto adverso del mundo que lo circunda.

En radical oposición, la sabiduría mística es una búsqueda desesperada y delirante, motivada por la conciencia del amor divino, que interpela al existente y demanda de este una correspondencia vital, la cual reclama -de quien atraviesa por el proceso místico- tanto el autoconocimiento como el conocimiento oscuro de Dios, en orden a la reorientación integral de sus proyectos, aficiones, deseos y afanes, gracias a la cual merece la contemplación infusa amorosa, que le otorga la capacidad de amar a Dios de modo sobrenatural. El ejercicio del amor confiere al existente conocimiento de sí mismo y de Dios, conocimiento que redunda en la humildad y el desprecio de sí e inflama con mayor fuerza la llama del amor a Dios.

Para referirse al vínculo entre inteligencia y amor, contemplación y fruición, San Juan de la Cruz habla de la mística como ciencia sabrosísima, con lo cual da a entender que si el místico se decide a salir de sí y de sus apegos para correr en pos de Dios, es por una experiencia originaria del amor divino que remueve su afectividad. En la mística sanjuanista, sabiduría y amor caminan juntos, aun cuando en ocasiones una se adelante y le cierre el paso al otro. El místico sabe (conoce y gusta) el amor de Dios. El místico se empeña en conocer a Dios porque desea amarlo de un modo perfecto. Ese amor fructifica en la apertura de la verdad de lo sacro; en una mostración esencial que se entiende, se siente y se gusta.

A propósito de cuanto se ha dicho, resulta esclarecedor traer a colación las palabras de Edith Stein cuando, al referirse a la "ciencia de la cruz", define dicho saber como "una verdad real y operante: como semilla que depositada en el centro del alma crece imprimiendo en ella un sello característico y determinando de tal manera sus actos y omisiones que por ellos se manifiesta y hace cognoscible" (Stein, $\mathrm{La}$ ciencia de la cruz, 32).

${ }^{19}$ San Juan de la Cruz, “Cántico espiritual B”, canción 37, párrafo 2.

${ }^{20}$ Ibíd., canción 33, párrafo 1. 
En el contexto de la experiencia mística, saberse mirado-amado por Dios es mirar-amar a Dios y mirar-amar a los otros en Dios, del mismo modo que Dios nos mira-ama. Por ello, en la oración, una de las peticiones recurrentes es ser mirado por Dios; porque si la ausencia y lejanía de Dios provocan pena, la esperanza de ser mirado por Cristo aviva la llama del amor que inspira al místico a dejarlo todo para seguir las huellas del que lo hirió con su amor al mirarlo. Rogar a Dios humildemente que se digne mirarnos es pedirle que nos capacite para reconocer su presencia amorosa y que nos dé la fuerza y la habilidad para corresponder a ese amor.

El fin sobrenatural de la vida, que se antepone al merecimiento de la gloria, es el ejercicio del amor perfecto. Cuando la amada del Cántico espiritual arriba a la unión mística con Dios, no busca como recompensa "la gloria que Dios le ha de dar, sino darse ella a él [en] entrega de verdadero amor sin algún respecto de su propio provecho" ${ }^{21}$. Dado que el amor-ágape no busca nada para sí, quien ama a Dios de modo perfecto no reclama como ganancia la perfecta visión de Dios, pues "el fin de todo es el amor [...] cuya propiedad es dar y no recibir, y la propiedad de el entendimiento, que es el sujeto de la gloria esencial, es recibir y no dar"22.

\section{Segundo principio místico: el amor} de Dios es absoluto y excluyente

Con el objeto de que el individuo realice el fin sobrenatural para el cual fue creado, es necesario que atraviese un arduo proceso de negación, renuncia y desasimiento, para quedar desnudo de los apegos que le impiden gozar de la unión amorosa con Dios. La necesidad de esto radica en el principio místico-teológico, según el cual “dos contrarios, según nos enseña la filosofía, no pueden caber en un sujeto"23.

Tan pronto reparamos en nuestras vidas, salta a la vista que gran parte de nuestra energía se consume en el deseo desordenado de los bienes finitos. Ejemplo de ello es el deseo desordenado de los bienes temporales (riquezas, oficios, hijos, parientes, etc.), naturales (hermosura, gracia, donaire, y complexión corporal, etc.), sensuales (tanto si proceden de los sentidos como de la imaginación), e incluso de los bienes naturales espirituales (buen entendimiento, discreción y otras facultades de la razón).

Ordinariamente, no solo deseamos poseer lo que la voluntad nos presenta como bueno; lo deseamos desordenadamente. El deseo desordenado o apetito es un

\footnotetext{
${ }^{21}$ Ibíd., canción 38, párrafo 5.

${ }^{22}$ Ibíd., canción 38, párrafo 5.

${ }^{23}$ Idem, "Subida del Monte Carmelo", Libro 1, capítulo 4, párrafo 2.
} 
movimiento de la voluntad que, al tener su origen en el deseo infinito de sentido infinito que define a la existencia, al desviarse del objeto que le es propio (la infinitud de Dios), da origen a actos y hábitos desordenados.

Los apetitos son movimientos desordenados de la voluntad que surgen cuando el deseo infinito de sentido infinito se dirige hacia los bienes finitos en vez de orientarse hacia Dios como su propio y esencial fin. El hecho de que sean realidades accidentales significa que no constituyen operaciones naturales ni sobrenaturales que correspondan por esencia a la voluntad y, por tanto, pueden ser negados.

Los apetitos ponen al individuo en una situación miserable porque lo orillan a buscar la satisfacción de su deseo infinito de sentido infinito en la posesión de bienes efímeros. Quien se engaña pensando que la variedad de lo efímero puede saciar su aspiración a lo infinito confunde el objeto propio de la voluntad con los objetos que se ofrecen a esta, inmediata y regularmente; y al hacerlo labra su propia desgracia, pues cuando "hubiere satisfecho su apetito, quedará más apretado y agravado; [pues] creció en su alma el calor del apetito y así caerá sobre él todo el dolor" ${ }^{24}$, proveniente de la insatisfacción de su deseo. El error consiste en que "dejando lo que solo puede satisfacer [Dios], [quienes así proceden] se apacientan en lo que les causa más hambre”25.

$\mathrm{Al}$ referirse al daño positivo que causan los apetitos, San Juan de la Cruz señala: "cánsase y fatígase el alma con sus apetitos, porque es movida y turbada de ellos [...] sin dejarla sosegar en [un] lugar ni en una cosa" ${ }^{26}$. La razón consiste en que los apetitos "siempre están pidiendo [...] y nunca se contentan" ${ }^{27}$ con la posesión de lo que persiguen. Encadenada por sus propios apetitos, la voluntad que se deja arrastrar por los apetitos impone siempre a los sucesos cotidianos un conjunto de expectativas condenadas a ser defraudadas.

Solo el encuentro con Dios en Cristo es capaz de satisfacer el deseo infinito de sentido infinito que nos es propio. Cristo es la única fuente de donde mana el agua capaz de saciar esa sed de sentido infinito. No obstante, cuando la voluntad está presa de los apetitos, es incapaz de reconocer en Dios el bien perfecto al que aspira su deseo infinito de sentido infinito. De ahí se deriva que el mayor daño que provocan los apetitos consiste en que "privan del Espíritu de Dios"28. Dado que "no pueden caber

${ }^{24}$ Ibíd., Libro 1, capítulo 6, párrafo 6.

${ }^{25}$ Ibíd., Libro 1, capítulo 6, párrafo 7.

${ }^{26}$ Ibíd., Libro 1, capítulo 6, párrafo 6.

${ }^{27}$ Ibíd., Libro 1, capítulo 6, párrafo 3.

${ }^{28}$ Ibíd., Libro 1, capítulo 6, párrafo 1. 
dos contrarios (según dicen los filósofos) en un sujeto [...] y afición de Dios y afición de criatura son contrarios" 29 , ocurre que "cuanto aquel apetito tiene de más entidad en el alma, tiene ella de menos capacidad para Dios"30.

El propósito de la purificación de los apetitos voluntarios es permitir que la voluntad recobre su libertad, a fin de que esté en condiciones de abrirse a la presencia infinita de lo divino. Se trata de ordenar la voluntad, sin despojarla de su dinamismo. En tal sentido, el mejor consejo para no impedir la unión con Dios y avanzar en el camino del desapego es: "cualquier gusto que se le ofreciere a los sentidos, como no sea para honra y gloria de Dios, renúncielo y quédese vacío por amor de Jesucristo, el cual en esta vida no tuvo otro gusto ni le quiso tener que hacer la voluntad de su Padre" ${ }^{\text {" }}$.

\section{Tercer principio: los medios deben ser proporcionados a los fines}

Otro principio más de la mística sanjuanista, "todos los medios han de ser proporcionados al fin, es a saber: que han de tener alguna conveniencia y semejanza con el fin, tal que baste y sea suficiente para que por ellos se pueda conseguir el fin que se pretende"32. El fin al que ser refiere San Juan de la Cruz es la unión mística con Dios, que consiste en conocer y amar a Dios del mismo modo que él se conoce y se ama a sí mismo en cada una de las personas de la santísima Trinidad.

La pregunta obligada es si los medios de los que el hombre dispone para conocer y amar satisfacen dicho principio; pero antes de responderla es preciso aceptar que a ciertos entes corresponden determinadas operaciones; y que, en virtud de su ser natural, los únicos medios de los que el hombre dispone para conocer son las operaciones de las facultades propias de su naturaleza: entendimiento, voluntad y memoria.

Aceptado lo anterior, el problema deriva de que tanto el ser del hombre como el conocimiento del que es capaz son naturales, mientras que el ser y el conocimiento que distinguen a Dios son de carácter sobrenatural. Por tanto, dada la falta de proporción entre ambos, de ello se deriva la incapacidad humana para conocer el ser sobrenatural de Dios, por sus solos medios.

En primer lugar, esto se debe a que, de acuerdo con la teoría del conocimiento que subyace a la teología sanjuanista, el principio de todo conocimiento radica en

\footnotetext{
${ }^{29}$ Ibíd.

${ }^{30}$ Ibíd.

${ }^{31}$ Ibíd., Libro 1, capítulo 13, párrafo 4.

${ }^{32}$ Ibíd., Libro 2, capítulo 8, párrafo 2.
} 
los datos que nos aportan los sentidos. Solo somos capaces de representarnos en la imaginación y en el entendimiento aquello de lo cual hemos tenido una experiencia sensible. Así mismo, en el orden natural, nuestra voluntad solo ama aquello que conocemos.

Sin embargo, a Dios,

...ni el ojo le puede ver ni cosa que se parezca a él, ni el oído puede oír su voz ni sonido que se le parezca, ni el olfato puede oler olor tan suave, ni el gusto alcanza sabor tan subido y sabroso, ni el tacto puede sentir toque tan delicado [y] tan deleitable ni cosa semejante; ni puede caer en pensamiento ni imaginación su forma, ni figura alguna que le represente. ${ }^{33}$

El ser sobrenatural no puede aprehenderse naturalmente.

Ahora bien, dado que sentido, imaginación y entendimiento son los únicos medios naturales de que el hombre dispone para conocer algo, cabe inquirir sobre la posibilidad de acceder a su comprensión indirecta, usando como recurso la analogía. San Juan de la Cruz objeta contra tal posibilidad:

...entre todas las criaturas superiores ni inferiores, ninguna hay que próximamente junte con Dios ni tenga semejanza con su ser, porque, aunque es verdad que todas ellas tienen [...] cierta relación a Dios y rastro de Dios [...] de Dios a ellas ningún respecto hay ni semejanza esencial [...]. Y por eso es imposible que el entendimiento pueda dar en Dios por medio de las criaturas. ${ }^{34}$

De acuerdo con San Juan de la Cruz, "ninguna noticia ni aprehensión sobrenatural [...] le puede servir de medio próximo para la alta unión de amor con Dios”35. Ello obedece a que dichas aprehensiones se ubican "debajo de algunas maneras y modos limitados, y la sabiduría de Dios, en que se ha de unir el entendimiento, ningún modo ni manera tiene ni cae debajo de algún límite ni inteligencia distinta y particularmente" 36 .

La analogía es un recurso que posibilita el conocimiento racional de Dios, partiendo del conocimiento del ser y atributos de las criaturas. No obstante,

...las criaturas, ahora terrenas, ahora celestiales, y todas las noticias e imágenes distintas, naturales y sobrenaturales, que pueden caer en las potencias del alma, por altas que sean ellas en esta vida, ninguna comparación ni proporción tienen

\footnotetext{
${ }^{33}$ Ibíd., Libro 3, capítulo 24, párrafo 2.

${ }^{34}$ Ibíd., Libro 2, capítulo 8, párrafo 3.

${ }^{35}$ Ibíd., Libro 2, capítulo 8, párrafo 5.

${ }^{36}$ Ibíd., Libro 2, capítulo 16, párrafo 7.
} 
con el ser de Dios, por cuanto Dios no cae debajo de género y especie, y ellas sí, como dicen los teólogos, y el alma en esta vida no es capaz de recibir clara y distintamente sino lo que cae debajo de género y especie. ${ }^{37}$

Si San Juan de la Cruz niega que la analogía sea un recurso apropiado para el conocimiento de Dios es porque considera que para que el conocimiento pueda realizarse, es menester que exista una semejanza unívoca y no solo análoga, entre el ser de lo que se pretende conocer (Dios) y el medio por el cual se busca conocer (la razón). No obstante, dado que entre la razón natural (que se sirve de aprehensiones provenientes de las criaturas para construir sus razonamientos) y el ser sobrenatural de Dios no hay una semejanza, de ello se sigue que la analogía no es un medio adecuado para la realización del fin sobrenatural para el cual fuimos creados.

\section{Cuarto principio: la fe es el único medio proporcionado para la unión con Dios}

En total consecuencia con el rechazo del conocimiento analógico como vía adecuada para el conocimiento del ser de Dios, el cuarto principio teológico de San Juan de la Cruz consiste en que la fe "es sola el próximo y proporcionado medio para que el alma se una con Dios"38. Si la fe es el "legítimo y próximo medio para la unión con Dios" 39 es porque satisface las exigencias de la regla filosófica según la cual "todos los medios han de ser proporcionados al fin [...] han de tener alguna conveniencia y semejanza con el fin" ${ }^{30}$.

Cabe aclarar que la fe de la que ahora se habla no es la aceptación o el asentimiento de la voluntad a un conjunto de verdades o artículos revelados. La fe de la que habla San Juan de la Cruz es "inteligencia mística y confusa o oscura” ${ }^{\text {” }}$. Es ciencia que no procede de ninguna facultad ni operación natural, infundida por Dios mismo en el existente, por la cual este entiende de modo sobrenatural el misterio de su amor. La fe mística que surge de la contemplación es experiencia amorosa sobrenatural que Dios infunde en el alma por gracia. Sin embargo,

\footnotetext{
${ }^{37}$ Ibíd., Libro 3, capítulo 12, párrafo 1.

${ }^{38}$ Ibíd., Libro 2, capítulo 9, párrafo 2.

${ }^{39}$ Ibíd., Libro 2, capítulo 30, párrafo 5.

${ }^{40}$ Ibíd., Libro 2, capítulo 8, párrafo 2.

${ }^{41}$ Ibíd., Libro 2, capítulo 24, párrafo 4.
} 
...la contemplación es ciencia de amor, lo cual, como habemos dicho, es noticia infusa de Dios amorosa, que juntamente va ilustrando y enamorando el alma, hasta subirlo de grado [en grado] hasta Dios su Criador; porque solo el amor es el que une y junta al alma con Dios. ${ }^{42}$

La fe es el medio para la unión con Dios, que anonada al entendimiento, para dejarlo "sin luz y a oscuras viendo", pueda gozar de la visión sobrenatural de Dios que, para el hombre, es noche oscura en esta vida. Para penetrar en el umbral de la experiencia unitiva con Dios es preciso sumergirse en la oscuridad que envuelve su manifestación esquiva, para lo cual "ha de ir careciendo el apetito [del gusto] de todas las cosas del mundo que poseía, en negación de ellas; la cual negación y carencia es como noche para todos los sentidos del hombre" ${ }^{23}$.

Ha de renunciar activamente a servirse de los únicos medios a su alcance para conocer y amar cuanto se ofrece a su experiencia natural para abrirse al encuentro con la faz nocturnal de una divinidad abismática, carente de determinaciones y límites precisos, tenebrosa, totalmente otra y por ello mismo seductora, capaz de envolver en su interior a quien penetra en el umbral de su acontecer.

\section{La fe: virtud teologal sobrenatural que posibilita el conocimiento del misterio de Dios}

Al explicar el cuarto principio de la mística sanjuanista se ha presentado una definición negativa de la fe sobrenatural. Se ha dicho que la fe no es un conocimiento natural y que, en consecuencia, no participa de la desproporción propia de todas las operaciones de las que el entendimiento, la voluntad y la memoria son capaces. Con todo, sigue en pie la pregunta de qué es la fe.

A pesar de que el origen, esencia e importancia de la fe sobrenatural son cuestiones que San Juan de la Cruz aborda en todas sus obras, considero que la expresión más acabada de lo que el santo presenta como esencia de dicha virtud teologal es el poema titulado "Entréme donde no supe. Coplas del mismo hechas sobre un éxtasis de harta contemplación”. A continuación me permito transcribirlo, para luego ensayar su interpretación, con el propósito de hacer manifiesta la esencia de la fe como virtud sobrenatural:

\footnotetext{
${ }^{42}$ Idem, "Noche oscura", Libro 2, capítulo 18, párrafo 15.

${ }^{43}$ Idem., "Subida del Monte Carmelo", Libro 1, capítulo 2, párrafo 1.
} 
Entréme donde no supe

y quedéme no sabiendo

toda sciencia trascendiendo.

Yo no supe dónde entraba,

pero cuando alli me vi, sin saber dónde me estaba,

grandes cosas entendi;

no diré lo que sentí,

que me quede no sabiendo

toda sciencia trascendiendo.

De pazy de piedad

era la sciencia perfecta,

en profunda soledad

entendida vía recta, que me quedé balbuciendo

toda sciencia trascendiendo.

Estaba tan embebido,

tan absorto y ajenado,

que se quedó mi sentido

de todo sentir privado,

y el espiritu dotado

de un entender no entendiendo

toda sciencia trascendiendo.

El que alli llega de vero

de si mismo desfallesce;

cuanto sabia primero

mucho bajo le paresce,

y su sciencia tanto cresce,

que se queda no sabiendo

toda sciencia trascendiendo.

Cuanto más alto se sube tanto menos se entendía, que es la tenebrosa nube que a la noche esclarecia; por eso quien la sabia queda siempre no sabiendo toda sciencia trascendiendo. 
Este saber no sabiendo

es de tan alto poder,

que los sabios arguyendo

jamás lo podrán vencer,

que no llega su saber

a no entender entendiendo

toda sciencia trascendiendo.

$Y$ es de tan alta excelencia

aqueste summo saber,

que no hay facultad ni sciencia

que le puedan emprender;

quien se supiere vencer

con un no saber sabiendo

toda sciencia trascendiendo.

$Y$ si lo queréis oir,

consiste esta summa sciencia

de la divinal Esencia;

es obra de su clemencia

hacer quedar no entendiendo,

toda sciencia trascendiendo.

El poema arranca con el desconcierto de quien se halla de pronto en un ámbito de realidad totalmente distinto del cotidiano, sin entender cómo ha ido a parar allí. Súbitamente, por obra de la apertura del misterio salvífico, el místico ingresa en un éxtasis, en un transporte que lo saca de su propia órbita para sumergirlo en una dimensión de lo real que le es ajena y desconocida. Por ello dice: "Entréme donde no supe". El origen del no saber es la extrañeza, que contrasta con la certidumbre de que la situación en que se halla lo convierte en habitante de otro mundo de sentido.

Arrancado de su mundo por el éxtasis de la contemplación, el místico prosigue diciendo: "y quedéme no sabiendo", para aludir la evidencia de que ninguna de sus capacidades naturales para conocer puede aplicarse a la experiencia sobrenatural del misterio salvífico. Avasallado por la experiencia contemplativa amorosa de Dios, el místico queda confinado a la inefabilidad donde permanece retenido cuanto no puede ser dicho clara ni distintamente ni, por tanto, puede ser transmitido a otros.

La experiencia de encuentro con el misterio salvífico es originaria y no tiene paralelo. El habla se sirve de construcciones previas, provenientes de estructuras tradicionales en las cuales se ha formado el individuo, cuya finalidad es nombrar diversos 
fenómenos que en nada se le asemejan. De ahí la incapacidad de hallar una palabra adecuada para una experiencia originaria e íntima, cuyo acaecer supone una ruptura y desestructuración de la cotidianidad regular.

Por causa de su encuentro con el misterio salvífico, cuando ha cesado la experiencia contemplativa amorosa, el místico está embriagado de ciencia divina. Cuando compara la iluminación con el conocimiento finito, limitado y falible que le aportan sus facultades naturales, reconoce la bajeza y nulidad de cuanto creía saber. Confiesa que habiendo quedado "toda sciencia trascendiendo", y al haber llegado a la contemplación, que es sabiduría oscura y amorosa de Dios, descubre a su "espíritu dotado de un entender no entendido", conforme a las operaciones naturales.

La sabiduría mística emanada de la contemplación infusa amorosa supone un ascenso, un vuelo hacia lo sagrado que otorga al individuo la oportunidad de vislumbrar la esencia divina. Durante tal ascenso, "cuanto más alto se sube tanto menos se entendía”. Ascender por la escala mística es renunciar a entender lo que no puede ser objeto de ninguna facultad ni operación natural. Porque "es de tan alta excelencia aqueste summo saber, que no hay facultad ni sciencia que lo puedan emprender; quien se supiere vencer con un saber no sabiendo irá siempre trascendiendo".

Ese saber, cuya dignidad, perfección y estatuto de ser, por cuanto proviene de Dios, supera tanto a la teodicea como a la teología. La mística es saber secreto en su doble aspecto de conocimiento y fruición de orden sobrenatural, que se distingue de cualquier otro tipo de experiencia por su objeto, por su medio, por su término y su fin.

Para referirse a la sabiduría mística, San Juan de la Cruz habla de la "la tenebrosa nube que a la noche esclarecía", echando mano de una metáfora proveniente de la experiencia cotidiana. La nube se interpone entre los rayos del sol y filtra su luz, permitiendo que solo una pequeña porción de ellos irradie su poder aclarador sobre algunos objetos y que sus perfiles cobren definición. La nube es una mediación sutil que impide la visión directa y plena del sol, insoportable para el ojo al que encandila y ciega por cuanto sobrepasa su habilidad natural.

La contemplación amorosa infusa es "tenebrosa nube que a la noche esclarecía", por ser causa del oscurecimiento y negación del ejercicio ordinario de las facultades naturales. En sí misma iluminación desbordante, la contemplación es un tipo de saber que excede los límites de la condición de ser del existente, cuya noticia es para este una tenebrosa nube que inunda y desborda su capacidad de comprensión con su claridad nocturna.

¿Por qué elegir la noche como símbolo de aquella experiencia que señala el tránsito del estado de principiante al de aprovechado? Edith Stein sostiene, sobre la noche cósmica, lo siguiente: 
No es propiamente un objeto en el sentido literal de la palabra. No está delante de nosotros y ni siquiera se sostiene por sí mismo. No es tampoco una imagen, entendida como figura invisible. Es invisible e informe. Y, sin embargo, la percibimos verdaderamente y está más próxima a nosotros que todas las formas y figuras [...]. Como la luz penetra con sus propiedades visibles todas las cosas, de la misma manera se las traga la noche y amenaza con tragarnos a nosotros también. Lo que en ella se hunde es algo más que nada; continúa existiendo, pero indeterminado, invisible e informe [...]. Nos priva del uso de los sentidos, impide nuestros movimientos, reduce nuestras fuerzas y nos arroja a la soledad convirtiéndonos a nosotros mismos en sombras y fantasmas. Es como un preludio de la muerte. ${ }^{44}$

La noche -nos dice la filósofa- no es objeto porque no es presencia; es la ausencia de toda presencia clara, que a partir de su acontecer queda embozada en el misterio de lo no mostrado, cuyo ocultamiento suscita una experiencia innegable. La noche no es imagen porque escapa a la visión. Es invisible y carece de forma. Es la causa misma de la invisibilidad que suspende. Más que entidad, la noche designa un ámbito, un abismo donde reposan en su hundimiento las cosas.

La noche mística no debe entenderse cósmicamente. No tiene su origen fuera del alma sino que brota de sus mismas entrañas y afecta solo al alma de donde nace [...] implica un hundimiento del mundo exterior [...]. Establece al alma en la soledad, la aridez y el vacío, liga la actividad de sus fuerzas y la angustia con los terrores amenazadores que en ella se ocultan. Sin embargo, también hay una luz en la noche, que descubre un nuevo mundo en lo más hondo del alma, y en cierto modo, ilumina desde dentro el mundo exterior que nos devuelve completamente transformado. ${ }^{45}$

Como la noche cósmica, la noche mística de la contemplación no solo comporta una faceta de oscuridad absoluta, sino también un aspecto luminoso. La noche cósmica aniquila la visión del mundo externo y deja al individuo en soledad. La noche mística le permite replegarse sobre sí mismo, en actitud serena, para demorarse ante la apertura de esa ilustración oscura que Dios opera en él por gracia, por más que no alcance a entender cómo ni por qué.

La contemplación es "tenebrosa nube" porque se interpone entre la clara y directa visión de Dios a la que el existente solo puede acceder en la gloria y el deseo de este último de poseerle en vida. Como la nube, la contemplación es un velo que

\footnotetext{
${ }^{44}$ Stein, La ciencia de la cruz, 74-75.

${ }^{45}$ Ibíd., 76.
} 
se interpone entre lo sagrado y lo profano; y que, al hacerlo, no solo oscurece y opaca cuanto envuelve en su seno -las facultades naturales para conocer-, sino que también permite que se filtre a través suyo un rastro de luz que invade al existente, haciéndole sentir y saber, amar y conocer la realidad absoluta que mora en su interior.

La experiencia contemplativa declarada en las coplas tituladas "Entréme donde no supe", tuvo lugar cuando su autor "estaba tan embebido". El modo de estar en el mundo que se despliega a raíz del acontecer mostrativo del misterio salvífico se caracteriza por la absorción en la experiencia que conduce al olvido del cuidado de sí. Arrobado por el éxtasis de la contemplación, el místico, amante eufórico de lo sagrado, está volcado hacia el Dios amado que se le revela mediante la "tenebrosa nube que a la noche esclarecía”. Todo su sentir está orientado hacia Dios, si por ello se entiende la disposición afectiva que por un lado lo conduce ante él, mientras que por otro lado es efecto de la contemplación.

El conocimiento místico es experiencia integral que permite al existente saber lo que siente y sentir cuanto sabe. Y por eso "consiste esta summa sciencia en un subido sentir de la divina esencia”. La contemplación es un sentir de lo divino porque es contacto directo entre lo humano y lo divino.

Dios es tiniebla para el entendimiento. Del mismo modo, por implicar un exceso de luz sobrenatural, la contemplación anonada y deslumbra al entendimiento de todos sus objetos naturales. Igual que la contemplación oscura amorosa en la que se revela, Dios es tiniebla y noche oscura para el entendimiento, que lo deslumbra y ciega, inundándolo con su luz excesiva para unirlo a sí. Por obra de la ilustración oscura de la fe, "la luz de la fe, por su gran exceso, oprime y vence la del entendimiento, la cual solo se extiende de suyo a la ciencia natural” ${ }^{\prime \prime 6}$.

Dios comunica su sabiduría en la experiencia contemplativa. Como fuente de donde mana la realidad por un derrame de sobreabundancia, Dios la conoce porque es causa eficiente y final de la misma. Aquello que piensa su entendimiento es la idea o el Verbo interior idéntico a sí mismo en esencia, engendrado desde la eternidad: la "sabiduría divina, que es el Hijo de Dios" ${ }^{47}$, por la cual todo fue creado; sabiduría de la que el espiritual solo participará cuando, habiendo arribado al matrimonio espiritual, “se una y transforme por amor en el Hijo de Dios" ${ }^{4}$.

\footnotetext{
46 Ídem, “Subida del Monte Carmelo”, Libro 2, capítulo 3, párrafo 1.

${ }^{47}$ Ídem, “Cántico espiritual B”, canción 37, párrafo 2.

${ }^{48}$ Ibíd., canción 1, párrafo 10.
} 
Por ser una experiencia interior, cognitio experimentalis de Deo (Santo Tomás, San Buenaventura), la contemplación es un encuentro íntimo y personal entre Dios y el espiritual que se da en "profunda soledad". Inmerso en el bullicio de los afanes que ligan y cohesionan una comunidad, quien añora el encuentro unitivo difícilmente encuentra las condiciones indispensables para tomar distancia de los apremios de su cotidianidad y retirarse a la soledad silenciosa donde mora el misterio salvífico. El místico se sumerge en su propia soledad para interponer una distancia entre él mismo y la vanidad del deseo que proviene del mundo. La soledad es para él un retiro, un desierto, sea cual sea la forma que ello asuma ${ }^{49}$.

La soledad mística no es encierro egoísta ni desprecio del mundo. El místico no se empeña en habitar en despoblado porque se considere mejor que quienes lo rodean o los desprecie. Se aleja porque comprende que no se conoce lo suficiente; y que a pesar de la nostalgia y el pesar motivados por su ansiedad de situarse cara a cara ante el misterio salvífico, no sabe cómo ni dónde buscar a Dios. Se aleja para desocultar un ámbito, para disponer una región donde pueda emprender su búsqueda espiritual sin perturbaciones externas.

Mediante la palabra, el individuo se hace oír por los otros y somete a su consideración las ideas que sustentan su posicionamiento. Hablar es una apertura de lo privado; es la automanifestación de quien habla ante su interlocutor. El lenguaje permite superar de algún modo el solipsismo al que nos condena la condición de individuos. Los amantes aprecian el silencio porque les permite olvidar la separación que hace de ellos seres individuales. No buscan verbalizar la unidad en la que anhelan diluirse sino deslizarse en ella.

El desnudo -y aquí me refiero tanto a la exhibición del propio cuerpo como a la entrega espiritual de sí- reclama como condición sine qua non el despojo interior de todo lo que estorba a la manifestación de quién se es. Lo que solo puede ocurrir, y

\footnotetext{
${ }^{49}$ Por citar solo un pasaje de la historia de la mística donde la inventiva humana se las ha ingeniado para hacer que el desierto irrumpa aun en la cotidianidad familiar, vale la pena recordar lo que se cuenta de Catalina de Génova: "el día posterior a la fiesta de San Benito (a instancias de su hermana, que era monja) acudió Catalina a confesarse [...]. Y de súbito, habiéndose arrodillado ante él, recibió en su corazón la herida del inconmensurable amor de Dios, con tan clara visión de su propia miseria y de sus faltas, y de la bondad de Dios, que casi cayó al suelo. Y con estas sensaciones de infinito amor, y de las ofensas que se le habían hecho a este dulcísimo Dios, se sintió tan grandemente alejada de las pobres cosas de este mundo por un efecto purificador, que estaba fuera de sí, por lo que lloró interiormente con ardiente amor [...]. Y retornó a casa, prendida y profundamente herida por tan grande amor de Dios [...]. Y recluyóse en una cámara, la más retirada que pudo hallar, con ardientes visiones" (Underhill, "La mística. Estudio de la naturaleza y desarrollo de la conciencia espiritual”, 209).
} 
aun esto parcialmente, en un espacio aislado donde pueda llevarse a cabo la seducción de los amantes y la entrega intermitente que culmina, según sea el caso, tanto en la explosión orgásmica como en la unidad espiritual.

La experiencia amorosa cancela la preocupación por todo aquello cuanto no sea el Amado. Solo indirectamente, el amante puede reparar en lo que refleja la figura y rastro del Amado. Esta idea, trasladada a la cuestión que nos ocupa, ayuda a comprender que aun cuando en el momento de la unión el místico es indiferente, e incluso experimenta molestia ante el contacto con sus semejantes, eso obedece a que su único deseo es unirse con el amor que habita la dimensión más profunda e íntima de su ser. Consumada la unión, por más que esto nunca se realice del todo, dado que si el movimiento del amor es infinito, jamás se puede hablar de un punto máximo en el acto de amar, y retorna al cuidado de sus semejantes a los que ama, como manifestaciones del amor primordial.

San Juan de la Cruz no es partidario de ese quietismo indiferente que busca el retiro para mejor complacerse del goce unitivo en detrimento de sus obligaciones como miembro de una comunidad a la que debe un servicio. Su misticismo no hizo de él, en ningún momento, un sujeto pasivo sino un amante del Dios sin modo al que veía no solo en el prójimo sino en la naturaleza misma cuya belleza y maravillas atraviesan las canciones del Cántico espiritual.

\section{La actualidad perenne de la doctrina sanjuanista sobre el origen y condiciones de posibilidad de la experiencia mística}

Sin necesidad de contra-argumentar ninguna doctrina filosófica sobre la crisis de la metafísica, la experiencia mística pone de manifiesto que Dios no ha muerto y que, mientras el género humano no desaparezca, tampoco lo harán la religión ni la mística. La razón reside en que, sin importar cuánto intente desviarse del fin sobrenatural para el cual fue creado, mediante el deseo de posesión y el goce de los bienes finitos, siempre y cuando cada uno de nosotros permanezca atento a lo que ocurre una vez que les damos alcance, solo podremos reconocer el vacío de sentido vital que pide ser llenado con la experiencia de Dios.

Es cierto que la imagen de Dios proveniente de la metafísica ha hecho crisis. Sin embargo, es necesario entender que el Dios de la fe no es siempre el Dios de la teodicea ni el de la teología. Y que la "muerte de Dios", entendida como el resquebrajamiento de una peculiar representación de lo divino, no decide nada, en favor ni en contra de la experiencia de Dios. Dicho de otro modo, el hecho de que la filosofía occidental 
haya puesto al descubierto la insuficiencia del concepto onto-teo-lógico de Dios, no cancela en ningún sentido la posibilidad del vínculo religioso con el misterio de Dios del cual dan cuenta la revelación y los testimonios místicos.

Si analizamos a fondo la cuestión, nos daremos cuenta de lo siguiente:

La desaparición de ingenuas, interesadas o manipuladoras afirmaciones e imágenes de Dios es tan indispensable para la experiencia verdadera de Dios como ese superar los propios gustos, los apegos, las propias representaciones de Dios a los que se refiere la interpretación de San Juan de la Cruz de la noche oscura desde la conciencia de que nada de todo eso es Dios. ${ }^{50}$

Pienso que un intento por rebasar el ocaso de la representación onto-teo-lógica de Dios consiste en asumir que el encuentro con Dios es una posibilidad de todos las épocas. A mi entender, la idea de que Dios está lejos de nosotros no es algo exclusivo de la posmodernidad nihilista y secularizada; es un pensamiento recurrente que, de vez en vez, asalta al hombre, en cuyo interior arde todavía el fuego del amor divino.

En todo caso, se debería reconocer que el encuentro con Dios se da en la historia: que el lugar por excelencia del encuentro con Dios no es la reflexión filosófica ni teológica sino la experiencia de la vida diaria: que es en la cotidianidad que nos toca vivir, marcada por la crisis de las representaciones tradicionales de Dios y la emergencia de nuevos movimientos más espirituales que religiosos, donde Dios irrumpe para transformarnos.

$\mathrm{Al}$ aceptar lo anterior, sostengo que la crisis de la metafísica, la sacularización y el nihilismo tienen un aspecto positivo: obligan al cristiano a confirmar su fe mediante la búsqueda de la experiencia personal de Dios. Hace tiempo, Karl Rahner afirmó: "El cristiano del futuro o será un 'místico', es decir, una persona que ha 'experimentado' algo, o no será cristiano, porque la espiritualidad del futuro no se apoyará ya en una convicción unánime, evidente y pública" ${ }^{\prime 1}$.

Tal como la interpreto, esa afirmación significa que después de la crisis de la metafísica, de la secularización y del nihilismo, la única forma de mantener vivo el cristianismo es el retorno a la experiencia de Dios.

El reto así enunciado no es menor: se trata de dejar a un lado el conocimiento de lo que la tradición "dice" acerca de Dios, para correr al encuentro del amado esposo Cristo, con la esperanza de hallar su presencia escondida. El propósito es acceder a un

\footnotetext{
${ }^{50}$ Martín Velasco, La experiencia cristiana de Dios, 175.

${ }^{51}$ Rahner, “Espiritualidad antigua y actual”, 25.
} 
encuentro directo con Dios gracias al cual estemos en condiciones de sostener, junto con Job, "antes te conocía de oídas, ahora te han visto mis ojos" 2 .

Con lo anterior no quiero decir que la teología no tiene ya posibilidades de generar un discurso sobre Dios capaz de poner de manifiesto los rasgos esenciales del misterio que lo envuelve. Es evidente que, si a alguien compete la reflexión rigurosa y sistemática sobre la representación de Dios, es al teólogo. Sin embargo, considero que el sustento último de todo discurso sobre Dios es la experiencia. Así, cuando el teólogo no ha participado de una experiencia intensa de unión con Dios, está obligado a prestar atención a quienes han realizado de modo radical el fin sobrenatural para el cual fuimos creados: los místicos.

De acuerdo con Karl Rahner, considero que el cristiano de hoy requiere -para afirmar su fe en medio de la increencia y la indiferencia acerca de Dios- no una doctrina, sino un camino que le permita arribar a la experiencia de Dios que le oriente en la subida al monte de perfección, en cuya cima mora la presencia escondida del Dios vivo y verdadero al que ninguna doctrina puede abarcar. Lo que el cristiano de hoy necesita no es ser indoctrinado; es una mistagogía.

La mistagogía es la que habrá de proporcionar la verdadera "idea de Dios" partiendo de la experiencia aceptada de la referencia esencial del hombre a Dios, la experiencia de que la base del hombre es el abismo, de que Dios es esencialmente el incomprensible, de que su incomprensibilidad, en lugar de disminuir, aumenta a medida que se le va conociendo mejor [...]. Esa mistagogía nos ha de enseñar concretamente a perseverar en mantenernos cerca de ese "Dios", en hablarle como a un "tú", en aventurarnos en su silenciosa oscuridad [...]. Naturalmente, en esa mistagogía cristiana ha de ocupar un lugar decisivo Jesús de Nazaret, el crucificado y resucitado. ${ }^{53}$

Desde mi punto de vista, la mejor forma de hablar sobre Dios es prestar oídos al modo como Dios ha hablado a los místicos, a la manera como su presencia amorosa se ha manifestado en su cotidianidad para transformarla. Solo entonces dejamos que sea Dios quien muestre la pauta sobre los conceptos que habrán de esclarecer la experiencia suscitada por su encuentro; solo entonces estamos a salvo de hacernos un Dios a la medida de nuestras exigencia filosóficas, teológicas o pragmáticas; solo entonces dejamos a Dios ser Dios.

En dicho contexto, es evidente la actualidad de los maestros espirituales como San Juan de la Cruz. El poeta místico enseña al hombre de su tiempo y al de ahora

\footnotetext{
${ }^{52}$ Job 42,5.

${ }^{53}$ Rahner, "Espiritualidad antigua y actual”, 26.
} 
que, frente a todas las posibilidades vitales que suelen seducirnos (el conocimiento de lo particular y de lo absoluto, el goce de los bienes sensibles y espirituales, la acumulación de riquezas, el poder, la fama, etc.), el fin para el cual fuimos creados es conocer la esencia escondida de Dios por fe sobrenatural y amar a Dios con el mismo amor-ágape que Cristo nos amó a todos en la cruz; y que aun cuando por nuestros propios medios no somos capaces de realizar dicho fin, la ayuda de la gracia que Dios infunde en contemplación oscura y amorosa nos capacita para llegar a ser aquello a lo que estamos llamados: dioses por participación.

A diferencia de quienes, con el propósito de ponerse a salvo de la dureza de la cruz de Cristo, sostienen que la santidad es un camino extraordinario para la salvación, reservado para unos cuantos a quienes Dios elige por razones que nos son inaccesibles, San Juan de la Cruz sostiene que Cristo murió para la redención de todos y por amor a todos, y que, en consecuencia, todos podemos ser místicos.

Al retomar la pregunta inicial de esta meditación, ahora podemos responder que la razón por la cual, a pesar de que la deificación es el fin sobrenatural para el cual fuimos creados todos, solo algunos lo logran. Ello se debe a que no todos desea participar de la cruz de Cristo.

¡Oh, si se acabase ya de entender cómo no se puede llagar a la espesura y sabiduría de las riquezas de Dios [...] si no es entrando en la espesura del padecer de muchas maneras, poniendo en eso el alma su consolación y deseo! ¡Y cómo el alma que de veras desea sabiduría divina desea primero el padecer para entrar en ella en la espesura de la cruz! [...]. Porque para entrar en estas riquezas de su sabiduría la puerta es la cruz, que es angosta, y desear entrar por ella es de pocos, mas desear los deleites a que se viene por ella es de muchos. ${ }^{54}$

Si en la época en que nos ha tocado vivir preguntamos hacia dónde es posible dirigirnos para buscar la presencia escondida de Dios, conocerlo y amarlo del mismo modo en que él se conoce y se ama en cada una de las personas de la santísima Trinidad y nos ama a cada uno, la respuesta consiste en que no hace falta cambiar de residencia. Dios sale a nuestro encuentro allí donde estamos.

El problema reside en que, para darnos cuenta de que Dios siempre nos está convocando a la realización del amor perfecto para cuyo ejercicio fuimos creados, es necesario silenciar nuestro ruido interno. Es preciso descentrarnos, para reconocer su llamado y responder "heme aquî". Solo entonces, cuando nos abrimos a su experiencia transformadora, comprendemos por experiencia lo que ningún discurso teológico ni

${ }^{54}$ San Juan de la Cruz, “Cántico Espiritual B”, canción 36, párrafo 13. 
filosófico puede dar a entender: que el misterio de Dios es el misterio de la cruz y de la resurrección.

En ese camino de búsqueda, el testimonio de hombres y mujeres que -como San Juan de la Cruz-fueron capaces de renunciar a cualquier gusto, apetito, contento y consolación que les impidiera asumir una actitud de total disponibilidad, de entrega plena al amado esposo Cristo, siempre será actual, debido a que sus palabras tienen el poder de expresar, mediante comparaciones, imágenes balbucientes y confesiones, la acción de Dios en el hombre.

\section{Conclusiones}

La actualidad e importancia para nuestro tiempo de estas aportaciones depende directamente de la respuesta acerca de si el misticismo propuesto por San Juan de la Cruz es una posibilidad abierta para todos, en cualquier circunstancia y época, o es una forma de vida a la que solo pudieron haber tenido acceso los escogidos por Dios hace siglos.

Es crucial determinar si el misticismo es una radicalización de la religión abierta a todo hombre que, por implicar un acto de libertad, puede ser rechazada o acogida por todos los individuos en cualquier tiempo y lugar (doctrina del llamamiento universal); o por el contrario, si solo los elegidos pueden acceder a la vida mística, sin que su voluntad tome parte en ello (doctrina de la predestinación).

Si la mística es cuestión de elegidos que han sido predestinados, estas páginas tienen un valor meramente anticuario: hablan de un tiempo y una experiencia pasada del todo ajena a los proyectos del hombre de hoy, que desconfía de la santidad y no alcanza a comprender que esa es la vocación de todo cristiano. Por el contrario, si San Juan de la Cruz tiene razón y la experiencia mística del amor-tal como él la entiende y a la que invita- está abierta para todos, la hermenéutica de su decir poético y doctrinal tiene sentido para el existente posmoderno en cuanto le ofrece la oportunidad de elegir un modo de vida estructurado por la experiencia del amor sobrenatural a la que también él está llamado.

Para San Juan de la Cruz, el fin sobrenatural del existente es amar y conocer a Dios como él lo hace, por participación de sus operaciones. Como ya se ha dicho, por sus propios medios, el hombre no puede conocer apropiadamente a Dios, toda vez que no existe proporción entre su habilidad natural y el ser sobrenatural de Dios. Sin embargo, de acuerdo con San Juan de la Cruz, el conocimiento de algo reclama como condición de posibilidad la proporción entre el medio por el cual se pretende conocer y la realidad que se desea conocer. 
Lejos de lo que pudiera pensarse, la conclusión de San Juan de la Cruz no consiste en que el hombre es incapaz de unirse a Dios por medio del conocimiento amoroso de su esencia. El poeta místico afirma que la mayor obra espiritual consiste en disponerse favorablemente para que, una vez liberado de los apetitos que le impiden unirse al Amado, Dios mismo sea quien mude el entender y amor humanos en divinos y proporcionados al fin de la unión.

Para San Juan de la Cruz, la única fuente de donde emanan el mérito, la justificación y la salvación es la unión mística que muda las operaciones finitas en divinas, con especial énfasis en el amor, que no solo vincula al místico con Dios sino que irradia su esplendor en la relación ética. Porque debido a la presencia por gracia del amor de Dios, a la presencia del Espíritu Santo en la voluntad, cuando atraviesa por la noche pasiva, el principiante coopera con su asentimiento a la experiencia oscura de la fe, renuncia al placer que encontraba en los ejercicios espirituales, y al hacerlo, se ejercita también en el cultivo de las virtudes morales infusas.

Para el cristianismo, es místico quien solo tiene su oficio y cuidado en el amor a Dios porque actúa bajo la convicción de que el sentido de la vida es amar a Dios del mismo modo que Dios nos amó en la cruz de Cristo. Esto solo acaece cuando, habiendo arribado a la fase final del proceso místico, la existencia está vuelta por completo hacia Dios, de modo que solo amar en perfección es su ejercicio.

Como el santo advierte, sin embargo, para arribar al conocimiento amoroso de Dios, la puerta es la cruz de Cristo. Por tanto, no debiera sorprender que, al ser la mística una experiencia de alcance universal, solo algunos hombres y mujeres están dispuestos a seguir las huellas del Amado hasta el calvario, para luego compartir su resurrección, y que, al ser tan intenso el sufrimiento de la cruz, haya quien esté dispuesto a emprender el arduo camino de la negación y del desasimiento, con el fin de disponerse favorablemente para que Dios le infunda el acto y el hábito de la fe sobrenatural, con el propósito de capacitarlo para la realización del fin sobrenatural para el cual todos hemos sido creados.

\section{Bibliografía}

Bocos, F. "Las criaturas en el proceso espiritual de San Juan de la Cruz". En Juan de la Cruz, espiritu de llama. Estudios con ocasión del cuarto centenario de su muerte (1591-1991), editado por O. Steggink, 581-596. Vacare Deo-X. Studies in Spirituality Supplement I. Roma: Institutum Carmelitanum, 1991.

Ferraro, J. San Juan de la Cruz y el problema mistico. La necesidad de un nuevo Concilio. México: Editorial Periodística e Impresora de Puebla, 1978. 
Gómez Caffarena, J. El misterio y el enigma. Madrid: Trotta, 2006.

González, L. "Aportaciones para una fenomenología de la mística". Revista Estudios de filosofía 47 (2013): 155-176.

. "Del concepto onto-teo-lógico de Dios a la comprensión fenomenológica de lo divino". Revista de filosofia de la Universidad Iberoamericana 13 (2011): 121-134. . "El amado del Cántico espiritual de San Juan de la Cruz: una fenomenología hermenéutica de la ágape como esencia del esposo Cristo". Cuestiones teológicas 41 (2014): 377-401.

- "Finitud, erotismo y experiencia mística en San Juan de la Cruz". Revista de filosofia Open Insight 6 (2013): 43-68.

- "Hacia una fenomenología del Cántico espiritual de San Juan de la Cruz". Ilu. Revista de ciencias de la religión 17 (2012): 59-76.

. "La revelación del Evangelio según San Juan: Dios es amor". Vida sobrenatural. Revista de teología mistica 694 (2014): 272-276.

Martín Velasco, J. Introducción a la fenomenología de la religión. Madrid: Trotta, 2006. . La experiencia cristiana de Dios. Madrid: Trotta, 1995.

Naval F. Curso de teología, ascética y mistica. Según las doctrinas de los grandes maestros de ella: San Juan de la Cruz y Santa Teresa de Jesús. Madrid: Coculsa, 1948.

Nygren, A. Eros y ágape. La noción cristiana del amor y sus transformaciones. Barcelona: Sagitario S. A., 1969.

Otto, R. Lo santo. Lo racional y lo irracional en la idea de Dios. Madrid: Alianza Editorial, 2007.

Rahner, K. "Espiritualidad antigua y actual”. En Escritos de teología VII, por Karl Rahner, 13-35. Madrid: Taurus, 1969.

Ruiz, F. Introducción a San Juan de la Cruz. El hombre, los escritos, el sistema. Madrid: Biblioteca de Autores Cristianos, 1968.

San Agustín. Confesiones. Madrid: Mestas Ediciones, 2003.

. "Textos de la Carta a los Romanos". En Obras completas de San Agustín. Vol. XVIII, 65-101. Madrid: Biblioteca de Autores Cristianos, 2003.

San Anselmo. Proslogion. Madrid: Tecnos, 1998.

San Juan de la Cruz. "Cántico espiritual B". En Obras completas, dirigida por Eulogio Pacho, 693-940. Burgos: Monte Carmelo, 2003. 
- "Llama de amor viva B". En Obras completas, dirigida por Eulogio Pacho, 947-1135. Burgos: Monte Carmelo, 2003.

. "Noche oscura". En Obras completas, dirigida por Eulogio Pacho, 535-686. Burgos: Monte Carmelo, 2003.

. "Subida del Monte Carmelo". En Obras completas, dirigida por Eulogio Pacho, 147-527. Burgos: Monte Carmelo, 2003.

Stein, E. La ciencia de la cruz. Burgos: Monte Carmelo, 2000.

Underhill, E. La mistica. Estudio de la naturaleza y desarrollo de la conciencia espiritual. Madrid: Trotta-Centro Internacional de Estudios Místicos, 2006.

Ynduraín, D. “'Y pacerá el amado entre las flores': la declaración en prosa”. En Juan de la Cruz, espiritu de llama. Estudios con ocasión del cuarto centenario de su muerte (1591-1991), editado por O. Steggink, 449-466. Vacare Deo-X. Studies in Spirituality Supplement I. Roma: Institutum Carmelitanum, 1991. 